\title{
Illicit Global Wealth Chains after the Financial Crisis: Micro-states and an Unusual Suspect
}

\author{
J.C. Sharman
}

\begin{abstract}
:
Since the financial crisis various supra-national initiatives have targeted banking and corporate secrecy, the conventional underpinnings of the illicit Global Wealth Chains through which money from tax evasion, corruption and other financial offences are passed across borders. This paper analyses the varying impact of these initiatives on the diverse types of Wealth Chains running through two stereotypical havens, Liechtenstein and the Seychelles, and one G20/OECD member rarely associated with illicit financial flows, Australia. Recent campaigns have had a significant impact on illicit Global Wealth Chains connected to micro-state tax havens, while leaving those to Australia unaffected. Even with reference to the micro-state havens, however, outside regulatory shifts have in some cases changed the flow or form of Wealth Chains by unintentionally creating new opportunities for offshore finance. Evidence is drawn from interviews and fieldwork in all three countries, secretly recorded footage of intermediaries explaining the workings of illicit Wealth Chains, and corporate and property records collected by a private investigator engaged by the author.

Acknowledgements:

I would like to thank Duncan Wigan, Leonard Seabrooke, John Chevis, Gill Donnelly, the Norwegian Research Council for the 'STEAL: Systems of Tax Evasion and Laundering' (\#212210/H30) grant, the participants at the various STEAL workshops, the Australian Research Council (grants DP120100937 and FT120100485), and the anonymous reviewers and editors of RIPE.

Bio:

J.C. Sharman is a professor at the Centre for Governance and Public Policy at Griffith University, Brisbane, Australia, whose research is focused on the global regulation of tax, corruption and money laundering, as well as the historical sociology of the international system.
\end{abstract}


After the outbreak of the financial crisis, the G20 and other associated multilateral organisations have broadened and deepened the fight against various related types of illicit financial flows, from tax evasion, to corruption, and the associated money laundering. This paper investigates the differential impact of these global regulatory shifts, employing the concept of Global Wealth Chains. The paper contrasts the experience of two classic micro-state tax havens, Liechtenstein and the Seychelles, with an 'unusual suspect' almost entirely neglected in relation to illicit financial flows, Australia. The goal is to gauge the variance in how the different Global Wealth Chains running through these countries have changed in response to the exogenous regulatory shifts, if at all.Rather than post-crisis global regulatory reforms constituting a Pareto-improving solution to common problems, these measures have had significant redistributive consequences.

The concept of Global Value Chains was first advanced to explain how the simultaneous integration of trade and fragmentation or dispersal of production are reconciled through a series of network types falling between the extremes of market and hierarchy (Gereffi, Humphrey and Sturgeon 2005). In this sense, it is firmly based on earlier work on transaction cost economics (Coase 1937; Williamson 1975; North 1990), and in particular the claim that firms exist to co-ordinate exchanges that may be uneconomic as market transactions, thanks to the costs of measuring the value of what is being exchanged ex ante, and ensuring all parties stick to the contract ex post. Crudely put, the innovation of Global Value Chains is to reject the markets-or-hierarchies binary, and instead divide the governance continuum of how value-chains are managed between pure market and pure hierarchical co-ordination into five segments: 
Market, Modular, Relational, Captive and Hierarchy. These different forms reflect in large part the varying extent of the scope for opportunism, asset specificity and co-ordination costs.

Though all of these five sub-types are explained in the Introduction to this special issue, three in particular are relevant to this article: Market, Modular and Relational (Gereffi, Humphrey and Sturgeon 2005: 86). Market chains are characterised by the exchange of relatively simple goodsin an environment of low transaction costs and asset specificity, reducing or obviating the need for significant institutional support for such exchanges to take place. Connections between buyers and sellers are transient and anonymous. Modular chains are those where relatively complex goods are exchanged, but institutional solutions have reduced this complexity and associated tacit knowledge such that transaction costs and asset specificity are once again fairly low. Thanks to these solutions, buyers and sellers can exchange freely with little lasting commitment to each other. In contrast, Relational chainsinvolve bespoke goods necessitating close interaction and a level of mutual dependence between buyers and sellers, who often find ways to credibly commit to cement on-going co-operation.

As discussed more extensively in the Introduction to this special issue, the concept of Global Wealth Chains adapts and expands these ideas. Retaining the focus on the need to knit together and govern geographically dispersed economic activity, the wealth chains in question are more likely to be intangible from start to finish (i.e. more likely to be concatenations of services rather than manufacturing), but also to have the primary purpose of avoiding accountability during wealth creation. This accountability may be tax, regulation, or other legal obligations. In the wake of high-profile examples of tax avoidance by firms like Google, Apple and Starbucks, critics have charged that much of the profitability of these firms is related to their 
management of Global Wealth Chains, rather than solely their management of global production processes through Global Value Chains (e.g. US Senate 2013; 'David Cameron Threatens more Tax for Starbucks and Amazon', The Times, 4 January 2013; ICIJ 2014).

While this paper draws on the Value/Wealth Chain framework, it also aims for a significant further extension. Whereas the firms above are practicing lawful tax minimisation strategies, the empirical material here is more often related to crime, specifically tax evasion, corruption, and the associated laundering of these funds. Second, while the cases do sometimes refer to firms engaged in the production of a good or service (licit, like legal advice, or illicit, like money laundering), much of the material presented below relates to individuals seeking to illegally preserve or obtain wealth without providing any sort of good or service. Despite these differences, however, the need to find institutional solutions to complex problems of economic co-ordination across borders remains. In many ways the need to solve governance problems is rendered all the more challenging by the fact that the activities in question are illegal (Lambsdorff 2013).

The findings below demonstrate not only the variation in illicit Global Wealth Chains across place, but also how they can change over time in response to environmental shifts. In this context, the changes are largely unintended and unanticipated, as regulatory campaigns have created new opportunities for wealth chains to form, even as they have sought to disrupt others, while leaving still other illicit chains unaffected. Thus with reference to Liechtenstein, EU regulatory change from 2003 prompted a shift from Relational towards Market chains, while more recent initiatives have seen the pendulum swing back again. In the Seychelles, arrangements are more Modular, with the volume of business through these chains increasing 
thanks to the uneven impact of recent moves to impose corporate transparency on competitor jurisdictions. Illicit flows into Australia, in contrast, have been unaffected, in that the Relational illicit chains persist undisturbed. Post-crisis shifts in the external regulatory environment have caused changes in Global Wealth Chains in the micro-states, positive and negative, intended and unintended, but have made little if any different to the country inside the key international clubs. Evidence is drawn from fieldwork and interviews primarily conducted in 2013 in Liechtenstein, the Seychelles and Australia, supplemented by investigative journalism and analysis performed by a private investigator engaged by the author to track down suspected stolen wealth in Australia. In particular, these patterns of change and continuity secondarily illustrate the potentially redistributiveconsequences of global regulatory initiatives, particularly when they are applied selectively. Although styled as a Pareto-improving effort to secure collective goods through addressing market failures and credible commitment problems, through their selective implementation these interventions have advantages some sectors and countries over others. Those insidethe G20 and OECD, like Australia, have faced far less pressure for change.

Why these three countries? Much of the attention with regards to illicit flows has focused on the usual suspects, micro-state tax havens, also known as Offshore Financial Centres or OFCs (Palan, Murphy and Chavangeux 2010). Though our knowledge remains patchy and our evidence incomplete and often unreliable, undoubtedly both micro-state tax havens and centres like New York, London and Paris are important in hosting illicit wealth. Yet second-tier centres, like those OECD member states outside the G7, have received little scrutiny so far in connection with the search for looted wealth (Switzerland being an exception). Although there are excellent studies of illicit financial flows in the South Pacific (e.g. Rawlings 2011; van Fossen 2012), these 
concentrate on small islands like Vanuatu and Nauru, rather than Australia. Of course, one reason for this omission could conceivably be that there is very little to tell. In presenting a detailed, primary source-based case study of Australia, however, this paper argues that we need to broaden our view of illicit financial flows to include not just the usual tax haven suspects, which have got the lion's share of attention, and the few leading financial centres like New York and London, which have increasingly come to the fore, but also the next rank back. Indeed, one of the major contributions of the Global Wealth Chain perspective is to reject the idea of a separate and distinct 'offshore finance'; offshore and onshore are part of the same financial ecology (see the Introduction to this issue). The case study of Australia shows how despite having only a modest presence in international finance, this country is nevertheless an important regional hub for the laundering of the proceeds of foreign corruption.

Because the same money may simultaneously represent the proceeds of corruption, tax evasion and money laundering, the paper relies on the increasingly common term 'illicit financial flows'. However, the definition of illicit financial flows itself raises problems. This phrase has been used to include more than just money derived from criminal offenses, capturing a wider range of related behaviour, variously including aggressive tax avoidance or capital flight (Reuter 2011). There is something to be said for avoiding the legal pedantry that, for instance, denies that Ferdinand Marcos was corrupt on the grounds that he was never convicted of any corruption offence in a court of law (Chaikin and Sharman 2009). Before countries criminalised the bribery of foreign officials such payments were not bribes in a strict legal sense. Kleptocrats may make their thefts legal by decree. Because this paper is a social science attempt to understand behaviour, rather than a black-letter law analysis, it adopts a broader usage rather than strict 
legalistic definitions (which in any case rely on earlier social constructions, see Picciotto 2007; Allridge 2008). By the same token, however, illicit financial flows cannot just mean 'flows of

money that are illegal, and other flows that are legal but which I nevertheless dislike', especially when this kind of conceptual slippage is hidden. To guard against this kind of conceptual stretching, and to keep the discussion focused, the paper concentrates on clearly criminal activities, rather than tax avoidance or capital flight. Before moving to the substance of the argument it is important to provide a brief background on the changing regulatory context, and in particular the international drive to counter cross-border illicit financial flows through promoting transparency.

\section{The Changing Regulatory Context}

Governments have always had an interest in promoting some measure of financial transparency, if only to raise sufficient tax revenue. Yet with growing fears about the impact of ‘the dark side of globalisation' in the late 1990s, new and existing international organisations began to work together to promote cross-border tax compliance and attack transnational crimes like money laundering, both of which were seen as thriving on financial secrecy (OECD 1998; FATF 2000). Although illicit financial flows had little if anything to do with the financial crisis unfolding from 2007, efforts to promote transparency were subsequently catalysed and reinforced by efforts to respond to this crisis, especially those spearheaded by the G20. Unilateral pressure from the US was often important in giving these new global standards teeth. The details of these initiatives have been extensively covered elsewhere (Drezner 2007; Vlcek 2008; Reuter 
2011; Sharman 2011; Jakobi 2013; Eccleston 2014), but the key priorities have been to push private financial intermediaries to collect more information on their clients, and to pressure governments to be more willing to share the resulting information with foreign counterparts. Particular areas of focus have been finding those who are in control of shell companies, trusts and other similar corporate entities (the 'beneficial owners'), and a step change in the amount of tax information exchanged between states. Albeit in fits and starts, these priorities have produced major changes in even the most secretive jurisdictions, but much less change in what are perceived as ‘onshore’ financial centres.

As part of new anti-money laundering standards, banks and other financial institutions must police their customers, and report suspicious activity to the authorities. In turn, international standards dictate that this financial intelligence should be made available to foreign law enforcement agencies (see Tsingou this issue on how the system operates on a 'regulate what you can see basis'). Tax and corruption crimes, which had been excluded from anti-money laundering provisions, have recently been brought into this framework (Jakobi 2013). Previously the understanding was that, because tax was a sovereign matter, governments had little obligation to provide tax information to foreign jurisdictions, except if mandated to do so by a bilateral tax treaty (Eccleston 2014; Johanessen and Zucman 2014). The OECD, backed up by the G20, completely up-ended this convention, however, to the extent that almost every single state has agreed to co-operate with foreign requests for tax information (OECD 2014). Led by the US, the standard has been recently ratcheted up even further, with countries increasingly expected to provide tax information unprompted on all foreign customers to these customers' home governments (Zagaris 2015). Stemming from worries about the impact of grand corruption 
on economic development, as well as spectacular examples of kleptocracy like those revealed by the Arab Spring, the World Bank, United Nations and G20 have pursued efforts to expose those financial centres hosting looted wealth (Reuter 2011). The most recent priority has been to ensure that companies and trusts can be linked back to the real person or people in control, known as the beneficial owner. Absent such information, cheap companies formed online can be used to mask transactions and hold de facto anonymous bank accounts (Findley, Nielson and Sharman 2014).

\section{Liechtenstein: From Relational to Market Wealth Chains and Back Again}

The example of Liechtenstein shows how external regulatory change aimed at combating illicit finance can lead to shifts in wealth chains, sometimes intended, sometimes unintended. As the material below demonstrates, there was a shift from Relational to a more Market model (explained below), which was then pushed back to a different Relational form. As noted earlier, the defining features of the Market form of wealth chains here are that the costs of switching to different buyers and sellers are low (i.e. low asset specificity). The products are largely simple and generic, with little skill required from suppliers, and little or no co-ordination required between particular buyers and sellers. In contrast, Relational chains involve much more mutual dependence between parties at different points in the same chain. This is because products are often individually differentiated, requiring considerable adaptability and skill from suppliers. As a result, these parties rely on informal or institutional mechanisms to manage repeated transactions (Gereffi, Humphrey and Sturgeon 2005). 
Aside from the lack of palm trees and beaches, Liechtenstein has long epitomised the stereotype of the tax haven and offshore secrecy centre in the popular and policy imagination. It has a long tradition of banking secrecy and asset-protection products like civil law foundations, common law trusts, and the hybrid Anstalt, peculiar to the Principality, being something between a company and a foundation (Doggart 2002). Liechtenstein built its finance industry in the 1920s after its economy was devastated by Allied sanctions in World War I (Beattie 2004). In the last few decades its customers were often Western Europeans looking to evade income, capital gains or inheritance tax, while from the early 1990s more of its clients have come from formerly Communist Europe and the developing world. These newer clients seek asset protection, either fearing political instability or an expensive divorce, with tax concerns being secondary. These clients often formed close and durable relations with the Liechtenstein firms safeguarding their wealth, for example also involving them in their estate planning (Author's interviews Liechtenstein 2004 and 2013).

The country's offshore sector had already come under heavy pressure from the previous round of multilateral initiatives in the decade before the financial crisis. In particular, the decision in June 2000 by the Financial Action Task Force to blacklist the country as 'non-co-operative in the fight against money laundering' saw disinvestment and a crisis of confidence. While the Liechtenstein government had backed down on this occasion, it had still firmly rejected demands to exchange information on tax cases. But in early 2009 G20 pressure on this front proved irresistible. Liechtenstein's vulnerability was accentuated when Heinrich Kieber, an employee of LGT Bank, closely linked with the Princely household, secretly copied clients' details and then sold the records to the German government. The Germans in turn passed 
on these records to other tax authorities, which created a series of media scandals as the financial activities of tax-shy clients were brought to light (Author's interviews, Liechtenstein 2013). Though they have recovered somewhat, deposits in Liechtenstein banks were lower in 2012 than in 2007, though it is difficult to separate the effects of the global recession from more specific industry and national effects (Liechtenstein Financial Market Authority 2013).

In a perverse way, some of the international initiatives have actually boosted Liechtenstein's financial sector, and effected a change from the more Relational chains to a more purely market form. An example is the European Union Savings Tax Directive. The subject of tortuous negotiations spanning 15 years, from 2003 the Directive mandated that EU members and European tax havens like Switzerland and Liechtenstein either supply information on non-resident EU citizens' bank interest income, or apply and remit a withholding tax on this income (Huizinga and Nielsen 2002). Seen as a crucial break-through at the time, the Directive ended up being a disappointment because it only covered individuals, not companies, trusts or other corporate entities (Hemmelgarn, and Nicodème 2009; Rixon and Schwartz 2012). For a few thousand dollars those EU account holders keen to continue evading tax could simply set up a company or trust, and then hold the account through this newly-created entity, rather than in their own name. This simple solution created a boom in Liechtenstein (and some other tax havens like the British Virgin Islands), as Swiss bankers in particular created a demand for legions of Liechtenstein entities for their account holders, regularly driving across the border with bundles of the relevant paperwork. In relation to the Savings Tax Directive, sometimes the account holders were told simply to 'sign here to make the problem go away', with the document in question creating a Liechtenstein trust or Anstalt. Firms in Liechtenstein could simply stamp 
and counter-sign the documents forming thousands of these entities, receiving ample fees without any connection with the underlying customer, who in turn would know nothing about the Liechtenstein provider. The combination of the G20 pressure and the Kieber scandal brought this simple ruse into question, however, and the fortunes of those approximately 280 predominantly small Liechtenstein firms creating these corporate vehicles has declined precipitously as a result (Author's interviews, Liechtenstein 2013 and Switzerland 2013 and 2015).

In response, the Liechtenstein government has tested a more radical solution in a bilateral agreement with Britain specifically designed to allow tax evasion money to be brought back into the legal economy, termed the Liechtenstein Disclosure Facility (LDF). The LDF allows those owing tax to the UK and holding 20 per cent or more of the assets in an Liechtenstein bank to make a clean breast of their financial affairs to the UK tax authorities, in return for much reduced penalties. Specifically, the standard penalties are 20 years' back taxes plus interest, up to a 100 per cent penalty, and possibly criminal prosecution. But under the LDF, the look-back period is only 10 years, the maximum penalty is 10 per cent, and there is a guarantee not to prosecute. What has made this offer especially attractive is that the steady drum-beat of data leaks, media exposés, and international financial information exchange agreements make it much more likely that tax evaders will be caught, and once they are under investigation these individuals are barred from using the safe harbour of the LDF. An industry publication notes:

Reasons for clients wishing to regularise their affairs seem to be fairly evenly balanced between the desire for peace of mind and the need to legitimately access the funds or to engage in effective inheritance planning. A desire not to criminalise the next generation is also a powerful factor (Airey 2011: 3). 
What makes the Disclosure Facility attractive as a model for the Liechtenstein authorities is that those looking to 'regularise’ their affairs can move their money from any jurisdiction into Liechtenstein, and then use the LDF, even if all the actual tax evasion took place in a third jurisdiction (typically Switzerland). Thus Liechtenstein banks (but not the company and trust formation sector that reaped a wind-fall gain from the Savings Tax Directive) have actually benefitted from an inflow of tax evasion funds, which are then declared, and afforded relatively lenient treatment. Clients have had to form a lasting relationship with local banks to qualify for the scheme, and banks have been keen to offer them a range of auxiliary financial services.

Whether or not this kind of deal will spread is uncertain. The attraction for third party governments is the prospect of a significant amount of extra tax revenue quickly, rather than the much longer and more drawn-out process of investigating evasion and pursuing assets through the courts. Many other European countries have offered tax amnesties for the same reason. However it is much less clear if these types of deals do in fact deliver the major new infusions of revenue that are hoped for. The Swiss were offered a similar deal to the LDF from the UK, but declined, something that in retrospect is seen by many as a mistake (Author's interviews, Liechtenstein 2013 and Switzerland 2013 and 2015). Instead, they reached a different deal whereby the client's identity is kept secret in return for a 19-34 per cent penalty payment, but this applies only to wealth in Switzerland and confers no protection against prosecution. A similar arrangement was vetoed in Germany on the grounds that it implicitly rewarded dishonest tax-payers over those who had done the right thing all along. The UK has concluded some similar agreements with its Crown Dependencies like the Isle of Man, but importantly these do not contain the protection against prosecution, and thus they are considerably less attractive. 
Thus Liechtenstein's traditional presence in more relational wealth chains briefly came to be supplanted by the simple market expedient of selling bulk trusts and Anstalten to tax-averse EU citizens as an unintended side-effect of the Saving Tax Directive. The combination of renewed pressure from the G20 post-2009 and the opportunity of the LDF saw the decline of market chains and the recrudescence of more relational arrangements.

The Seychelles: Modular Wealth Chains

Although the separate categories are more analytical than strictly empirical, offshore finance in the Seychelles is of a more modular cast, falling between the market and relational forms common in Liechtenstein. The mainstay of the sector is selling offshore shell companies, a relatively low-margin high-volume business. However, although the companies are formed to a generic template, which means there is low asset specificity on any particular transaction, they are usually established for a particular end-user, who typically selects the name of the company. Furthermore, these companies may be stitched together in more complicated corporate structures, as for example when company A is director or owner of company B. While there is a fairly standardised routine for forming companies, conducting the necessary due diligence, and lodging the relevant paperwork, it is not just a matter of stamping, signing, and waiting for the fees to roll in. Packaging shell companies in this manner allows relatively complex financial products to be sold with low transaction costs and asset specificity.

The Seychelles has been furthered removed from the epicentre of the campaign against tax havens, being beyond the reach of the EU, but has still felt the same pressures from the G20, 
OECD and others. Unlike Liechtenstein, the Seychelles has very little banking, with its financial sector instead comprised of around 60 corporate service provider firms selling offshore companies (Author's interview, Seychelles 2013). Importantly, most of these companies are used for legal and legitimate commercial purposes, such as holding companies. The offshore sector in the Seychelles is of much more recent provenance than Liechtenstein's, being created only in 1995, a product of a hard currency crisis that forced the government to look beyond the mainstays of fish and tourism (Author’s interviews, Seychelles 2005 and 2013; Shillington 2009). In a disastrous early attempt to attract foreign funds, in the 1995 Economic Development Act the government promised immunity from prosecution and extradition for any crime committed outside the Seychelles for any individual investing at leat \$10 million in the country. Both the initial legislation and subsequent revisions in 2006 were written by outside lawyers, often those working for offshore firms. Since the creation of the offshore registry, around 120,000 companies have been formed, although many of these have become inactive. The market is predominantly Eastern European, especially the Soviet successor states (Moscow and the Seychelles are in the same time zone), with some custom from Africa, East Asia and Western Europe. Much of the money from Russia often comes via Cyprus, thanks to the latter’s advantageous tax treaty network and geographical proximity, and is then held in a bank in Hong Kong, Switzerland or Mauritius in the name of a Seychellois company (Author's interviews, Seychelles and Mauritius, 2013). The Seychelles has managed to often stay ahead of international pressure, perhaps because the Seychelles is actually more compliant with standards on beneficial ownership of companies than most G20 members, including the United States and Britain (Findley, Nielson and Sharman 2014). Nevertheless, the Seychelles is no stranger to 
illicit flows and media scandals even well after the Economic Development Act.

A particularly embarrassing incident was a sting carried out in the Seychelles by journalists from Al-Jazeera who impersonated a corrupt senior official from Zimbabwe associated with that country's diamond industry and the official's lawyer. In footage secretly recorded with a hidden camera, the 'lawyer' explains: 'My client is from Zimbabwe and then [sic] he's the liaison officer between the Zimbabwean government and the rich diamond mines.' The local provider replies 'Yep, we don't want to know that. That's the sort of thing we can't have knowledge of. If we had knowledge of that we'd have to put it forward, so I haven't heard a word you've said in the last couple of minutes'. Another provider replaces sins of omission with sins of commission in suggesting the formation of one shell company with an associated bank account. He then continues:

Assume you have one million dollars you want to deal with. It’s there with you in cash, OK? We may have to create another company, and that company will be a consultant company. It charges you monthly or weekly ' $\mathrm{X}$ ' amount on all sorts of transactions, and you organize for payments to be deposited into that company's account, OK? For payment of your fees and charges. And, as such, you finally get your money, quietly (Al Jazeera 2012).

In response, the Seychelles authorities objected that the journalists had neglected to mention in their report that most providers had refused any contact once the nature of the deal became clear, and that the regulator quickly withdrew the two providers' licences (Author's interview, Seychelles, 2013).

Akin to the benefits of the LDF for the Liechtenstein banking sector, the Seychelles 
company formation sector has received something of a windfall from efforts to improve compliance elsewhere. Here rather than governments or international organisations driving change, however, the media and private financial institutions are at least as important. In April 2013, a group called the International Consortium of Investigative Journalists (ICIJ) based in Washington issued a co-ordinated press release with several of the world's leading newspapers. This summarised the results of a trove of information on tens of thousands of offshore company owners(ICIJ 2013). The information came from two financial services firms, Commonwealth Trust Services in the British Virgin Islands, and Portcullis Trustnet, based in Singapore, but with offices in the Cook Islands and several other offshore centres. Gerard Ryle of ICIJ received the information in a hard drive with 240 gigabytes of files sent to him anonymously (Author's interview, Washington DC, 2013). This huge leak of information was a grave embarrassment to the British Virgin Islands, the market leader in the provision of offshore companies, and hence the Seychelles' main competitor. The British government also began to take a closer interest in its Caribbean dependency's corporate registry, a further point of concern for those using shell companies, as regulation and fees both look likely to increase in the near future (Author's interviews, London 2013 and 2015).

Even more important was the fall out from a $\$ 1.92$ billion penalty imposed by the United States government on HSBC for complicity in money laundering after a report from the Senate Permanent Subcommittee on Investigations in 2012 (US Senate 2012). In response, HSBC compliance reform made it much harder for BVI companies to hold accounts with the bank (see also Rua, this issue). HSBC had decided to review the offshore corporate entities that generated the largest number of Suspicious Transaction Reports from its internal reporting systems. 
Because BVI companies are by far the most numerous kind of offshore entity, it was not surprising that they also generated the largest number of such reports. Objections from the BVI government and private firms about the faulty logic at work were to no avail (Author's interviews London and Switzerland 2013 and 2015). Given that most shell companies require bank accounts, and that HSBC had been one of the largest providers, Seychelles companies immediately became much more attractive as a result of the BVI's misfortunes, with incorporations in the latter down by 23 per cent in the last quarter of 2013 ('Going Overboard', Economist, 29 May 2014).

Though the pressure on offshore centres looks likely to continue well into the future, the Seychelles, like Liechtenstein, now finds itself on the OECD's tax whitelist, often applying higher standards that major onshore centres, and still enjoying considerable inflows of capital, a combination that few observers would have expected. External shifts have not changed the modular form of the wealth chains connecting the Seychelles, but they have increased the volume of business running through these networks. The drive for compliance and transparency has thus had very uneven effects offshore, penalising some havens, as expected, but creating opportunities for others, transforming some wealth chains while reinforcing others. The section below turns the spotlight away from micro-state havens and towards a detailed look at Australia's role as a previously unknown haven for looted wealth. It illustrates both the durability of Relational chains, and the selective enforcement of the global regulatory initiatives.

Australia as 'Another Cayman Islands': Relational Wealth Chains 
Both recent research into grand corruption and international policy measures drawn up in response have emphasised the importance of following the money trail to determine where corrupt senior officials hide their stolen assets. The answer is generally that wealth looted from poor countries is held in rich countries with large, stable financial centres, often those which share colonial or other historical ties with the victim country (World Bank/UN 2007, 2009, 2011; Global Witness 2009; 2011). The evidence below suggests that Australia plays such a role in hosting wealth stolen by corrupt senior officials from Papua New Guinea. It is important to note, however, that there is evidence of illicit funds from many other countries in Australia as well. The Chinese government has named Australia as the third-largest host of corruption funds secreted out of China (People’s Bank of China 2008). A 2015 report from Swiss NGO Bruno ManserFonds alleged that the former Chief Minister of the Malaysian state of Sawarak had laundered \$30 million of corruption funds in Australia (Bruno Manser Fonds 2015; Author’s interview, Switzerland, 2015). A December 2013 report from the OECD ranking its members' measures to counter inward illicit financial flows placed Australia in the second-worst position, behind only Poland (OECD 2013) (the governments of Australia and Canada, also poorly ranked in the report, unsuccessfully tried to cut out this unflattering verdict (Economist, 'Rich Smell', 21 December 2013). The material below is however focused on the Papua New Guinea (PNG) example, both to focus the discussion, and because it has been possible to collect important new primary data on illicit financial flows.

In terms of the Global Wealth Chains framework, the flows here most closely approximate the Relational form. As noted earlier in connection with Liechtenstein’s banking industry, relational forms involve considerable mutual dependence between the different parties 
in a wealth chain. Rather than fleeting exchanges between a multiplicity of buyers and sellers, there are long-term relations and large investments of tacit knowledge and mutualcommitments. In this case corrupt officials, lawyers, and real estate agents face considerable shared risks, not least because if the Australian government chose to stop ignoring the problem, these parties could be prosecuted for corruption and money laundering offences. Though there are common patterns to this laundering process, as discussed below, there is no standard template as with Seychellois offshore companies.

Papua New Guinea achieved independence from Australia in 1975, and now has a population of around 7 million. Recent strong economic growth is overwhelmingly based on a minerals and energy boom focused on gold, copper, oil and especially gas. Unfortunately, there are strong signs of the 'resource curse' experienced by other developing countries, especially in the coincidence of rapid growth and endemic corruption (Ross 1999; Barma 2014). These problems go back at least a decade. Thus two leaked US government cables from 2006 and 2008 described the PNG government as an example of 'Ponzi politics', in which mineral wealth and \$400 million in annual Australian aid payments have served 'more to enrich the political elite than to provide social services or infrastructure'. The PNG government was said to represent 'an appalling spectacle of disregard for governance ... this government, and the current crop of leaders on the national scene, have presided over a steady, nationwide deterioration of services—closure of health centres and schools, collapse of effective policing and a steady rise in violent crime’ (Wikileaks 2006, 2008). The same source revealed that Australian government officials were in the habit of privately referring to the PNG government as a 'totally dysfunctional blob’. 
Lest it be thought that these sentiments can be dismissed as the patronising judgments of the white former imperial masters and a distant super-power, it is worth looking at local sources. The PNG anti-money laundering unit has estimated that up to half of the taxes owed to the government are never collected, thanks to corruption-enabled tax evasion (PNG FIU 2010, 2). Furthermore, estimates from local police officials suggest that up to half of the government's revenue that is collected is then stolen by senior public officials ('Billions Lost to Fraud, Says Yakasa', The National, 16 February 2011; Koim 2012). A 2009 report from the PNG Parliamentary Public Accounts Committee, gives some indication of the scale of corruption:

By 2006, the Constitutional and statutory scheme of accounting and accountability for the management of public monies, had collapsed. The Committee respectfully advises the National Parliament that this collapse of accountability and responsible, lawful and competent fiscal management was, and remains, a direct threat to the viability and civil stability of the Nation and the health and welfare of our citizens (PNG Parliamentary Public Accounts Committee 2009, 1).

The report revealed how the Department of Finance was systematically corrupt, and had stopped paying any attention to the wishes of parliament or cabinet as to how government revenue was spent. The report was suppressed and its recommendations ignored. In June 2014 a warrant was issued for the arrest of the Prime Minister Peter O’Neill in connection with corruption offences ('PNG Prime Minister O’Neill Served with Arrest Warrant Related to Fraud Allegations', Sydney Morning Herald, 16 June 2014). The Prime Minister responded by firing the chief of police and cutting all funding to the country's anti-corruption unit ('Peter O’Neill Sacks Top 
PNG Policeman and Shuts Down Corruption Watchdog', Guardian, 18 June 2014; Author's interviews,Australia 2014, 2015).

Wealth Chains from Papua New Guinea to Australia

As a result of former colonial ties, PNG enjoys close links with Australia. Although Australia does not host a global financial hub like London or New York, it is the world's 14th-largest economy, and the largest financial centre in the South Pacific. That the problem of corruption funds from PNG being laundered in Australia has got any publicity at all is very much thanks to action from Port Moresby, and not Canberra. Thus in 2011 the head of PNG's newly-created anti-corruption Task Force Sweep referred to Australia as ‘another Cayman Islands', a haven for dirty money. The same official, Sam Koim, later gave a high-profile controversial speech on the problem to an audience of Australian bankers. After referring to his own country as a kleptocracy and noting that Australia had never repatriated so much as a single cent of PNG corruption funds (a fact that remains true in late 2015), Koim spoke of the activities of corrupt PNG officials in Australia as follows:

They have bought property and other assets, put money in bank accounts and gambled heavily in your casinos and have never been troubled by having their ill-gotten gains taken off them... Be under no illusion, these people have chosen Australia as their preferred place to launder and house the proceeds of their crimes because it is easy. Cairns is only a short flight and property can be bought off the plan without permission. The financial system is stable and, it has been, up 
until now, extremely easy to get their money into your system (Koim 2012).

This verdict is supported by testimony before the Australian Senate by AUSTRAC (Australian Transaction Reports and Analysis Centre, the financial intelligence unit), which stated:
AUSTRAC considers the Pacific a priority region for regulatory engagement and information exchange given the large number of Australian financial institutions operating branches across the Pacific and the level of money laundering, crime and corruption in the Pacific. Australia is a significant destination country for funds derived from corrupt activities within the region. (AUSTRAC 2008, 3, emphasis added).

In what he thought was an off the record meeting in May 2013, the Australian Federal Police Senior Liaison Officer in Port Moresby Steve Mullens stated that 'half a billion' kina (c. USD 200 million) of corruption funds flows from PNG to Australia each year. Finally, the 2015 review of Australia by the Financial Action Task Force once again belies Canberra’s insouciant attitude towards foreign corruption funds in concluding'Australia is seen as an attractive destination for foreign proceeds, particularly corruption-related proceeds flowing into real estate, from the Asia-Pacific region’ (FATF 2015: 7). How do the relevant wealth chains work?

The Relational wealth chains in this case rely on the services of three professions: bankers, real estate agents and lawyers, discussed in turn below. Of the three, banking is by far the most regulated sector, and thus would seem to provide the best safeguard against dirty money. Banks are covered by extensive reporting obligations to AUSTRAC, and they have a strict legal duty to perform 'Know Your Customer' checks with respect to new and existing 
account holders. As a result, Australian government officials interviewed by the author on the record maintain that, because any significant flows of corruption funds would have to go through the banks, and because the banks are well regulated, corruption proceeds are not a significant problem for Australia. But confidential interviews, as well as experience from equivalent foreign jurisdictions, suggest that this complacent attitude is fundamentally mistaken (Global Witness 2009; World Bank/UN 2009; US Senate 2012; Financial Services Authority 2011).

Australian bankers earlier indicated privately to the author that they believed the federal government did not take the issue of holding the proceeds of foreign corruption seriously (a view confirmed by the 2015 FATF report, see p.57), and so the banks took a correspondingly relaxed view of this risk. Similarly, these bankers indicated that they took a tolerant view of accepting the proceeds of corruption in their Southeast Asian and South Pacific subsidiaries and branches, including PNG. Once the funds are accepted at an overseas branch of an Australian bank, it is a relatively simple matter to transfer them to Australia. Especially when it comes to their private banking presence, Australian banks suggest that this aspect of their operations would simply be uneconomical if they were to take rigorous precautions to screen out suspect wealth, though this is more a concern in Southeast Asia than in the South Pacific.

Many senior PNG officials maintain extensive real estate holdings in the Australian state of Queensland, including those named in connection with corrupt activities in various PNG government reports, and even those formally charged with corruption and other criminal offences in PNG. Particularly when residential property is bought 'off the plan' (i.e. from a developer before the property is built, as opposed to buying existing property), there are no checks carried out on the source of foreign funds, and no duty to report suspicious transactions 
(Australian Parliament 2014).

To ascertain the size of the problem, and test the Australian government's official position that there are no significant corruption funds in the country, the author took on the services of a private investigator specialising in financial crime. Queensland property records are available online in two databases (RP Data and CITEC), and for a relatively small fee the records can be searched by the owner's name. These databases are generally used by real estate agents (realtors). Crucially, they provide the name of the owner, as well as such information as the last sale date and price, and in some cases pictures of the property, and scans of the original mortgage documents, showing the name of the relevant bank and the lawyer involved, if any. It is important to point out, however, that most of this information ultimately derives fromthe state land registry and the official companies registry, augmented by publically available sales information. The commercial databases collate rather than create most of this material.Having gained access to this information, the next step was to draw up a list of names of those individuals charged for corruption offences in PNG, and individuals named in connection with corrupt conduct in official PNG government enquiries (59 from the Department of Finance Inquiry, plus from 28 Task Force Sweep), and then match these against the databases to determine property ownership. The second was to search for these individuals on the Australian company registry to see if they featured as directors or owners of companies that in turn owned property in Queensland.

The result was that 203 properties owned by individuals and companies charged with or named in connection with corrupt activities in PNG were found in Queensland, valued by last sale price at AUD 86 million. Using Google Earth the physical location of these properties could 
then be mapped, showing that many corruption-tainted senior officials own property in the same neighbourhoods (sometimes directly next door to each other), use the same lawyers, and buy from the same few property developers. (The author provided this information to the Australian government, which then blocked the author's access to any further interviews about this matter with Australian government officials, and tried to do the same with respect to PNG government officials). In terms of the overall results, the legal significance is that it is a criminal offence for Australian banks to handle funds where there is a reasonable suspicion that these funds represent the proceeds of corruption (under the provisions on recklessness and negligence in division 400 of the criminal code). Yet in practice this did not preclude mortgages being issued even when the individual was charged with serious criminal offences in PNG, and when this information could be found with a simple Google search. The list of properties compiled by the private investigator is unlikely to be the complete record for Queensland, and does not include data from the other five Australian states.

In some cases it was possible to spot deliberate attempts to hide ownership. Thus one senior public official sold his property at a loss to a company owned by a trust, which turned out to be controlled by the same official. The wording of the trust deed seems to have been designed to omit the official's name. It specifies that the beneficiary of the trust is the official's wife, who is named, and the wife's spouse, i.e. the official himself, who is not named. Given the capital loss on the sale and the transaction fees, this move makes little sense from a commercial point of view, but a great deal of sense if the aim is to hide and protect criminal proceeds.

At this point it may be worth stepping back for a momentto briefly consider the practicality and ethics of employing a private investigator for academic research. On the one 
hand, this choice may be seen as a technical matter of employing specialised research assistance and skills that are otherwise unavailable. For example, very few social scientists are likely to have forensic accounting skills, or experience with the analyticaland networking software packages particular to this field. The biggest problem with studying illicit flows and criminal behavior is a lack of hard evidence; taking on the services of professional investigators ameliorates, though definitely does not solve, this problem. Yet it is the broader ethical issues that may be more important. Is it appropriate for scholars to act as some sort of vigilante? Conventional notions of research ethics (rightly) fixate on avoiding harm to those we study. Yet if it is a choice between exposing corrupt practices that serve to impoverish already marginal populations, andstaying silent, it would seem that either choice may well harm at least some subjects.

Returning the modalities of bringing illicit wealth into Australia, if banks and real estate are two common elements of the illicit wealth chains, the third closely related link is lawyers. A succession of investigations by various official bodies into corruption in PNG have named prominent law firms and dozens of individual lawyers and recommended that they be disbarred and/or prosecuted (PNG Inquiry into Department of Finance 2009; PNG Parliamentary Public Account Committee 2006). Often the lawyers in question have been able to win injunctions against these reports being published (though they are available on the web nonetheless), and prior to late 2013 no action follow-up action was ever taken. An official may transfer funds from his personal account to his law firm's trust account in PNG, which then transfers these funds to the trust account of its Australian counterpart office. The funds are then used to buy property. The high degree of trust involved between the parties enabling these transactions illustrates the 
Relational nature of the wealth chain. In such cases it is very unlikely that the bank transfers would be flagged as suspicious and thus come to the attention of the anti-money laundering system. Law firms' trust accounts often have a high volume of funds from different clients passing through, and therefore even quite large transfers for property purchases are unlikely to stand out, especially in the case of large law firms.

Akin to the Al Jazeera exposé referenced earlier in connection with the Seychelles, secretly recorded footage released in June 2015 similarly provides a stark example of illicit Relational Wealth Chains between Papua New Guinea and Australia. Working for the NGO Global Witness, a would-be investor approached a PNG law firm looking for assistance on how to secure ministerial approval for a land purchase, mentioning that 'he has some big ministerial mouths to feed'. A partner at the firm, a former Australian crown prosecutor, provided advice on paying off ministers after the Global Witness impersonator notes that he 'would struggle with a brown bag situation'.

Small dribs and drabs are the only way to go... It would have to be something that didn’t raise suspicions, something that was ostensibly commercial. The days of banging a million bucks into his secret numbered account in Singapore is over. Another partner at the firm (whose brother is a minister convicted of corruption charges and a close friend of Prime Minster Peter O’Neill) suggests: 'You want to make that payment off shore', in this case meaning Australia. He goes on to explain the procedure for passing the bribe to the minister via inflated legal bills:

You engage us, we engage him. When we do our bills, we do one bill to you and you pay us and we send his money off to Australia, to his Australian account... 
We normally engage a guy called [the name is bleeped out, but refers to a senior Brisbane-based Australian lawyer and Queen's Counsel]. Normally if it’s through the law firms they don't usually ask questions (SBS Dateline 2015).

The case of EremasWartoto is a rare example of action by the Australian government against PNG corruption in Australia, but it is an exception that proves the rule of general indifference (Author’s interviews, PNG government officials, 2013; Baker and McKenzie 2013). Wartoto is currently charged with misappropriating AUD 30 million in collusion with a minister and several senior public servants in PNG. Learning that the charges were immanent, he fled to Australia in August 2011. He used a car hire company he owned in Cairns to sponsor him for an Australian work visa. On 24 August 2011 the PNG government asked that the visa not be issued, given the criminal charges and outstanding warrant for Wartoto's arrest. The request was ignored and the visa granted in September. The PNG government then asked the Australian government that Wartoto be returned to face charges. The Australian government agreed with Wartoto's lawyers that he was too sick to travel (suffering 'fatigue'), even though during this period Australian government records show him travelling to Fiji, Indonesia, Singapore, Malaysia and the Solomon Islands. Having compiled this information, two Australian journalists then broke the story during the first day of the Australian Prime Minister's visit to Papua New Guinea in May 2013 so as to cause maximum embarrassment (Author’s interview, Australia, 2014). The story hit the papers on a Friday, the following Monday the Australian Foreign Minister cancelled Wartoto's visa, belatedly endorsing the PNG government request of August 2011. Subsequent action showed that Wartoto held four accounts with major Australian banks, five properties in Australia (two held by trusts with a lawyer acting as trustee and one with an outstanding 
mortgage), as well as the assets of his car hire company (Australian Federal Police Restraint Order 2013).

An even bigger case relates to Paul Paraka, currently charged in Papua New Guinea with 50 corruption and money laundering offences, and accused over his career of corruptly obtaining almost \$450 million of PNG government funds (Author’s interviews, Australian Federal Police 2013; PNG government official 2014 and 2015). Until his arrest Paraka, himself a lawyer, owned PNG's largest law firm and controlled several others. His influence was such that he had earlier convinced a judge to grant a court order specifying that the police give him seven days' notice before executing any search warrant on his properties, despite the law not allowing for the issuance of such an order. The arrest warrant for Paraka could only be issued thanks to the decision of the Chief Justice of the PNG's highest court to over-rule a lower court. Paraka is a close associate of many past and present cabinet members. A PNG government investigation in 2009 named Paraka as at the centre of a \$300 million scandal of over-charging the government for legal services. Though the report was not tabled, thanks to an injunction Paraka's firm won in an outlying court in murky circumstances, in practice the report circulated on the web, and thus even the most perfunctory Know Your Customer procedure would have found that Paraka was the subject of very serious allegations. Like the Wartoto case, there are strong links with Australia. Paraka had four separate 'wives' scattered along the East Coast of Australia, each of whose accommodation he paid for, which necessitated holding Australian bank accounts, both in a personal capacity and in association with the law firms he owned and controlled. Between February 2012 and February 2013 \$2.5 million was transferred directly from PNG to Paraka’s Australian accounts, the allegations of corrupt conduct again proving no obstacle to accessing the 
Australian financial system (Baker and McKenzie 2013).

To sum up, the case study of Australia is important for several reasons. To repeat the point made from the start, a focus extending beyond just the usual suspect micro-states complicates the idea of illicit financial flows as a morality play pitting the forces of progressive global governance against a few small,deviant jurisdictions. It also demonstrates the limits of recent global initiatives. What is notable about the Relational illicit wealth chains connecting Papua New Guinea and Australia is how little they have been affected by the broader international context, despite the priority the G20, OECD, World Bank and other bodies have placed on disrupting the flow of looted wealth from poor countries to rich ones. While Australia has received bad ratings from bodies like the FATF and OECD, this has not translated into the sort of sustained political and economic pressure experienced by Liechtenstein, the British Virgin Islands or other micro-states. Theoretically, it shows that even what might seem to be fairly simple transfers of stolen wealth from victim to host country, in fact rely on an intermediary stratum of skilled professionals forming close, asset-specific links with those at either end of the chain.Even in the absence of determined, preventive action by the authorities, thetransient, anonymous transactions that define Market chains, or the standardized package deals common in Modular chains, are not sufficient for the task at hand.

\section{Conclusions on Illicit Global Wealth Chains}

Global Wealth Chains allow assets and income to be protected, stored and transformed in such ways as to block the ability of national and international authorities to regulate or gain a 
purchase on that wealth. What do these three case studies and the concept of Global Wealth Chains tell us about the impact of post-crisis reforms to counter illicit financial flows? The first conclusion is that the concept or metaphor of chains and networks is much more apposite than the methodologically nationalist idea that illicit wealth is heaped up in vaults in one particular country, stereotypically a micro-state tax haven. Even for relatively simple products these chains tie together on- and offshore countries, as well as developing and developed, making the simple 'onshore finance' (good) and 'offshore finance' (bad) dichotomy a very poor guide to understanding. Global Wealth Chains enable us to form a much more complete understanding of these kinds of transnational flows.

For example, a simple chain involving Liechtenstein might start with a Russian oligarch contracting a Liechtenstein service provider to set up a foundation directed by a Swiss lawyer, which in turn owns a Jersey company to hold property in London, a Cypriot company to hold property in France, and a British Virgin Islands company to hold shares and other investments in a variety of third countries, all of which are hidden from the Russian authorities. For the Seychelles a Ukrainian firm may establish a Cypriot company to own a Seychelles company with bank accounts in Hong Kong to generate false consultancy payments to cancel out tax liabilities at home. For Australia, a PNG senior government official steals money and then uses a local law firm's trust account with an Australian subsidiary bank in PNG to transfer money to a related law firm's account in Australia to make a payment to a real estate agent and thence property developer. A further similarity is the extent to which Global Wealth Chains overlap and inter-penetrate with legitimate wealthand value chains, in particular the services provided by different types of professional financial intermediaries, thus serving to blur the separation 
between the criminal and licit economies.

If these multi-node networks are common across the three case studies, there are also clear differences between the micro-states and Australia. The primary concern of the financial centres in Liechtenstein and Seychelles for the last decade and a half has been a series of international regulatory initiatives, with those driven by the G20 being only the most recent and intrusive example. The implications of this are captured in a press release from the Liechtenstein regulator that may just as well have come from any other micro-state tax haven:

Access to foreign markets is the lifeblood of the Liechtenstein financial centre, given its international orientation and limited home market. With the increasing regulatory pressure, the threshold for the right to develop markets is being pushed higher and higher... With harmonised application of rules, the leeway for individual countries is continuously being diminished (Liechtenstein Financial Market Authority press release 6 May 2013).

Many observers, including a surprising number in offshore centres, have taken this logic to be a death sentence for tax havens. But the experience of the Seychelles' wind-fall gain from the British Virgin Island's problems, and the ability to 'regularise' what would otherwise be criminal money permitted by the Liechtenstein Disclosure Facility, illustrate the potential of global regulatory campaigns to actually create new business opportunities offshore. International regulatory initiatives can transform wealth chains, as in the case of Liechtenstein's movement from Relational to Market and back, reinforce existing chains, as with the Seychellois company formation business, or make no difference either way, as seen with reference to Australia place in Relational chains through which corruption proceeds are exported from Papua New Guinea. 
Thus even when regulatory campaigns have effects, these are not necessarily those that were expected or intended. In principle, such measures as the automatic exchange of tax information between governments, and efforts to render the ownership of companies transparent should have dismantledmany illicit wealth chains, but matters do not seem to be turning out that way. Two connected more general implications follow from these findings.

The first is to re-emphasise the point made so convincingly by Barnett and Duvall (among others) that global governance is at least as much a process of coercion and redistribution as a series of technocratic, Pareto-improving institutional fixes for market failures, credible commitment problems, and common bads (Barnett and Duvall 2004; see also Drezner 2007). Moving from scholarship to policy, going beyond the usual suspects in illicit financial flows is even more important for policy-makers than it is for academics. The various international clubs like the G20, FATF and OECD have recently and very reasonably moved from the process of laying down new international rules, towardsassessing whether these rules are actually effective. To the extent that new standards can really make a difference, the relatively small minority of powerful countries that dominate these clubsmust be willing to subject themselves to the same degree of scrutiny and accountability as they have imposed on others. 


\section{Bibliography}

Airey, Simon. 2011. 'The Liechtenstein Disclosure Facility and the UK/Swiss Agreement', Banken Magazin, Liechtensteinischer Bankenverband (December), pp.20-23.

Al Jazeera.2012. 'How to Rob Africa'

http://www.aljazeera.com/programmes/peopleandpower/2012/11/201211714649852604.html

Alldridge, Peter. 2008. 'Money Laundering and Globalization'.Journal of Law and Society 35(4): 437 - 463.

Australian Federal Police. 2013. Restraining Order filed against Eremas Wartoto, 26 April 2013, District Court of Queensland.

Australian Parliament. 2014. 'Report on Foreign Investment in Residential Real Estate'. House of Representatives Standing Committee on Economics. Canberra.

AUSTRAC. 2008. Testimony before the Australian Senate Committee on Foreign Affairs, Defence and Trade Inquiry into the Economic and Security Challenges Facing Papua New Guinea and the Other Island States of the Southwest Pacific. Canberra.

Author's interviews: Vaduz, Liechtenstein, 2004 and 2013; Victoria, Seychelles, 2005 and 2013; Port Louis, Mauritius, 2005 and 2013; Brisbane and Canberra, Australia 2014 and 2015; Geneva, Zurich, Basel and Bern, Switzerland, 2003 and 2015; London, United Kingdom, 2013 and 2015; Washington DC, United States, 2013.

Baker, Richard and Nick McKenzie. 2013. 'Alleged PNG Crime Boss on 457 Visa Wanted over Theft of \$30m', The Age, 10 May 2013.

Baker, Richard and Nick McKenzie, 'PNG “Dirty Money” Trail Leads to Australia', The Age, 19 June 2013.

Barma, Naazneen H. 2014. 'The Rentier State at Work: Comparative Experiences of the Resource Curse in East Asia and the Pacific'. Asia and the Pacific Policy Studies1 (2): 257-272.

Barnett, Michael and Raymond Duvall (Eds).2005. Power and Global Governance. Cambridge: Cambridge University Press.

Beattie, David. 2004. Liechtenstein: A Modern History, London: IB Taurus.

Chaikin, David and J.C. Sharman. 2009. Corruption and Money Laundering: A Symbiotic Relationship. New York: Palgrave.

Coase, Ronald H. 1937. 'The Nature of the Firm', Economica 16 (4): 386-405. 
Doggart, Caroline. 2002. Tax Havens and their Uses. London: Economist Intelligence Unit.

Drezner, Daniel W. 2007. All Politics is Global: Explaining International Regulatory Regimes. Princeton: Princeton University Press.

Eccleston, Richard. 2014. The Dynamics of Global Economic Governance: The Financial Crisis, the OECD, and the Politics of International Tax Co-operation. Cheltenham: Edward Elgar.

Financial Action Task Force. 2000. Review to Identify Non-Co-operative Countries or Territories: Increasing the World-wide Effectiveness of Anti-Money Laundering Measures. Paris.

Financial Action Task Force. 2015. Anti-Money Laundering and Counter-Terrorist Financing Measures: Australia: Mutual Evaluation Report. Paris.

Financial Services Authority. 2011. Banks’ Management of High Money-Laundering Risk Situations. London.

Findley, Michael G. Daniel L. Nielson and J.C. Sharman. 2014. Global Shell Games: Experiments in Transnational Relations, Crime and Terrorism (Cambridge: Cambridge University Press).

Gereffi, Gary, John Humphrey and Timothy Sturgeon. 2005. 'The Governance of Global Value Chains’. Review of International Political Economy 12 (1): 78-104.

Global Witness. 2009. Undue Diligence: How Banks do Business with Corrupt Regimes. London.

Global Witness. 2011. International Thief Thief; How British Banks are Complicit in Nigerian Corruption. London.

Huizinga, Harry and Spren Bo Nielsen. 2002. 'Withholding Taxes or Information Exchange: The Taxation of International Interest Flows'.Journal of Public Economics 87 (1): 39-72.

International Consortium of Investigative Journalists. 2013. Offshore Leaks Database. Available at https://offshoreleaks.icij.org/search

International Consortium of Investigative Journalists. 2014. 'Luxemburg Leaks: Global Companies' Secrets Exposed’. Available at http://www.icij.org/project/luxembourg-leaks.

Jakobi, Anja. 2013. Common Goods and Evils? The Formation of Global Crime Governance. Oxford: Oxford University Press.

Johanessen, Niels and Gabriel Zucman. 2014. 'The End of Bank Secrecy? An Evaluation of the G20 Tax Haven Crackdown’.American Economic Journal: Economic Policy 6 (1): 65-91. 
Koim, Sam. 2012. 'Money Laundering in Australia of the Proceeds of Corruption in PNG'. Speech at the AUSTRAC Major Reporters Meeting, Sydney, 4 October 2012.

Lambsdorff, Johann Graf. 2013. 'Corrupt Intermediaries in International Business Transactions: Between Make, Buy and Reform.’ European Journal of Law and Economics 35 (3): 349-366.

Liechtenstein Financial Market Authority. 2013. Annual Report. Vaduz.

North, Douglass C. 1990. Institutions, Institutional Change and Economic Performance. Cambridge: Cambridge University Press.

OECD. 1998. Harmful Tax Competition: An Emerging Global Issue. Paris.

OECD. 2013. Measuring OECD Responses to Illicit Financial Flows. Paris.

OECD. 2014. Standard for Automatic Exchange of Financial Account Information: Common Reporting Standard. Paris.

Palan, Ronen, Richard Murphy and Christian Chavagneux. 2010. Tax Havens: How Globalization Really Works. Ithaca: Cornell University Press.

Papua New Guinea Parliamentary Public Accounts Committee.'Inquiry into the Public Accounts of the Government of Papua New Guinea for Financial Year 2006’. Port Moresby.

Papua New Guinea Government. 2009. Commission of Inquiry Generally into the Department of Finance: Final Report. Port Moresby.

Papua New Guinea Financial Intelligence Unit. 2011. 'Due Diligence in Relation to Government Cheques and Payments’. Port Moresby.

People’s Bank of China. 2008. A Study on Methods of Transferring Assets Outside China by Chinese Corruptors [sic] and Methods for Monitoring this Problem. Beijing.

Picciotto, Sol. 2007.Constructing Compliance: Game Playing, Tax Law, and the Regulatory State.Law \& Policy 29(1): 11-30.

Rawlings, Gregory (2011) 'Relative trust: the Vanuatu tax haven and the management of elite family fortunes' in Mary Patterson and Martha Macintyre, eds. Managing Modernity in the Western Pacific St Lucia, Queensland: University of Queensland Press.

Reuter, Peter (Ed). 2011. Draining Development? Controlling Flows of Illicit Funds from Developing Countries. Washington: World Bank.

Rixon, Thomas and Peter Schwartz. 2012. ‘How Effective is the European Union’s Savings Tax 
Directive? Evidence from Four EU Member States’.Journal of Common Market Studies 50 (1): 151-168.

Ross, Michael L. 1999. 'The Political Economy of the Resource Curse'.World Politics 51 (2): 297-322.

SBS Dateline. 2015. 'Dirty Money: How PNG Cash in Reaching Australia’. 23 June. See: http://www.sbs.com.au/news/dateline/story/dirty-money-how-corrupt-png-cash-reaching-australi a.

Sharman, J.C. 2011.The Money Laundry: Regulating Criminal Finance in the Global Economy (Ithaca: Cornell University Press).

Shillington, Kevin. 2009. History of the Modern Seychelles. Houndsmill: Macmillan.

US Senate. 2010. Keeping Foreign Corruption out of the United States: Four Case Histories. Washington DC.

US Senate. 2012. US Vulnerabilities to Money Laundering, Drugs, and Terrorist Financing: The HSBC Case History. Washington DC.

US Senate. 2013. Offshore Profit Shifting and the U.S. Tax Code: Part 2 (Apple Inc.). Hearings transcripts from the Permanent Subcommitte on Investigations 21 May available at: https://www.hsgac.senate.gov/subcommittees/investigations/hearings/offshore-profit-shifting-an d-the-us-tax-code_-part-2.

van Fossen, Anthony. 2012.Tax Havens and Sovereignty in the Pacific Islands. St Lucia, Queensland: University of Queensland Press..

Vlcek, William. 2008. Offshore Finance and Small States: Sovereignty, Size and Money. Houndmills: Palgrave.

Wikileaks 2006: http://wikileaks.org/cable/2006/07/06PORTMORESBY274.html\# http://wikileaks.org/cable/2008/11/08PORTMORESBY222.html.

Wikileaks 2008: http://wikileaks.org/cable/2008/06/25PORTMORESBY00026.html\#

Williamson, Oliver E. 1975. Markets and Hierarchies: Analysis and Anti-Trust Implications. New York: Free Press.

World Bank/United Nations. 2007. Stolen Asset Recovery: Challenges, Opportunities and Action Plan. Washington.

World Bank/United Nations. 2009. Politically Exposed Persons: A Policy Paper on Strengthening Preventive Measures. Washington DC. 
World Bank/United Nations. 2011. The Puppet Masters: How the Corrupt Use Legal Structures to Hide their Stolen Assets and What to do About It (Washington D.C.: World Bank).

Zagaris, Bruce. 2015. 'Ethical Issues in Offshore Planning: Developments in the Aftermath of Automatic Exchange of Information'. Paper presented at the ALI International Trust and Estate Planning August 13-14, San Francisco, CA 